\title{
Sketch and Literacy
}

\author{
Anam Fadlillah \\ Universitas Negeri Surabaya \\ (anam.fadlillah@gmail.com)
}

\begin{abstract}
Identity is known as the concept of how people come to understand themselves through the "worlds" they participate in and how they relate to others within and outside of these worlds. However, their identity that is constructed within their figured worlds give significant impact to their literacy practices, in which their literacy event, unconsciously, showed their identity and figured worlds that they participate in. This paper investigates one post-graduate student's literacy event, sketching, by using the concept of figured worlds, in which it focused on figuring out how the figured worlds construct her identity in her literacy practices. The data were collected by taking photographs of the literacy events and interviewing to find out her cultural life, family, and social life that construct her identity. The findings of the study showed that somebody's literacy events have a lot of implicit meaning rather than just a product of literacy practices.
\end{abstract}

Keywords: identity; figured worlds; literacy events; literacy practices.

Common people think that their literacy practices and literacy events that they produced are purely based on their identity without any interference from the environment around them. In other words, they believe that it has nothing to do with their social, culture, family life where they live in. In fact, their literacy practices, anything they write and read, and their literacy events, any artifacts that they have and produced in their life, could actually draw their identity, in which it showed where, with whom they live, and etc. implicitly (Barton, Hamilton, \& Ivanic, 2000; Phal \& Rowsell, 2005). As it is found that students' interest will determine their literacy practices, such as students who love sport will likely prefer to read sport magazine or newspaper, and so forth. Gender will also likely to influence their literacy practices, such as girls usually prefer to read novel book, while boys prefer to read sport news and etc. (Luttrell $\&$ Parker, 2001). The idea of literacy has been broadened that it is not only focused on the skill of reading and writing in the school, but also set of social practices that people usually do in their daily activities mediated by written text, in which happened in different domain of life. There are three domains of life where the literacy events usually happened; they are home, school, and work-place. However, it is found that some literacy practices do not happen in any of these domains, and this situation is called "third space" (Barton et al., 2000; Phal \& Rowsell, 2005). 
This paper focuses on investigating a post- graduate female student's literacy practices in the home domain. The study aims to figure out students' identity formation, whether her literacy practices were purely based on her identity or they were influenced or constructed by her figured worlds. This research idea was based on the theory of Phal \& Rowsell (2005) that home domain constructs somebody's identity, and generally the figured worlds that somebody participates in constructing somebody's identity, in which it is conceptualized by Holland, et al. (1998).

The notion of figured worlds was first introduced by Holland et.al. (1998). In general, it is some kind of place that somebody's identities were produced. However, figured worlds are also included to the historical phenomena people involved in or engaged in. Figured worlds develop through the action of their participants, such as somebody who are involved in the sport world, he will likely produce his identity within this figured world and somehow, this kind of figured world will develop based on its participants' works. Figured worlds are like activities that involve social encounters, in which the role of participants' positions is very important. Hence, we could not enter some figured worlds because of our social position and rank. Since figured worlds involve social encounters, they are also organized and reproduced socially by dividing the roles of the participant as like an institutional sense.

Looking into the notion of figured worlds as historical phenomena that involve social encounters, in which the participants position as the important role, it is believed that the figured worlds that somebody participate in will construct their identity through the social interaction among them (Holland et al., 1998; Phal \& Rowsell, 2005). Since the notion of literacy has been broadened as social practices, somebody's identity that constructed within the figured worlds will influence the literacy practices they are doing, such as the book they like to read, and anything they write were the reflection of their identity (Barton et al., 2000; Luttrell \& Parker, 2001).

The notion of literacy in Indonesia is still known as the ability of reading and writing in the school. However, the notion of literacy has been revised since there is a gap between student's literacy practices in and outside the school, where some students' social interaction is also mediated with a text, either printed or not. Based on this finding, the expertise of literacy revised the notion of literacy as social practice, which means that students were involved with activities that mediated by a text is almost every time, in their social activity, cultural activity, and etc. (Phal \& Rowsell, 2005). The concept of literacy as social practice can be understood as a series of social practice mediated by written text, in which it has different types based on the domain where the literacy practices happened (Barton et al., 2000).

There are three domains where the literacy practices occur; school domain, workplace domain, and home domain. However, the literacy practices that do not include to these domain is called third space (Barton et al., 2000; Phal \& Rowsell, 2005). But, this paper will not be talking about those domains; it will focus only on home domain, where somebody does literacy practices at their home.

There is a relation between literacy and identity, since the notion of literacy as social practices, meanwhile identity is created through the social practices we do (Phal \& Rowsell, 2005). Dealing with identity that is constructed by figured worlds somebody participates in, in which affect their literacy practices, it can be concluded that figured worlds could be changed by the literacy practices that the participants show. Further, it is found that literacy could change somebody's identity from common person to be someone that has a big prestige in the society, in which it is called the triumph of literacy (Pratiwi, 2014). Investigating a post-graduate female student's literacy practices based on home domain, this paper aims to answer the following questions: 
a) what are the post-graduate female student's figured worlds she participated in?; and b) how do her literacy practices draw her identity of the figured worlds she participated in?

\section{Method}

This study employed descriptive qualitative approach in library research, since the data collected from the sketches and interview were analyzed based on the references related to the focus of the study. The data were taken from the sketches that the subject has drew and also from the interview done with the subject. These data were then analyzed based on the references related to the topic of the study that is about literacy and identity.

The data were analyzed in order to answer the two problems of the research. Due to its qualitative nature, the data were then displayed in narratives, not number. The what and how questions were answered by describing the sketches and results of interview. The validity of the results was ensured by confirming to the subject.

\section{Results and Discussion}

\begin{abstract}
Vignette: Rina's hobby in the spare time

It was Rina (not the real name) who made the pictures in this paper. She is 25 years old woman who is in first semester of post-graduate studies in State University of Surabaya. She likes to read novel, and watch anime movies. And in her spare time, she draws some cartoon figure that she has watched, sometimes, she added the picture by some motivation sentences.
\end{abstract}

Based on the interview, it is found that, the reason she drew these picture is because she got bored of doing something. So, by drawing something she thinks that it would make her time more productive rather than doing nothing. She started drawing since she was a kid, it is because her father also has a similar talent, in which it motivated his children to like drawing. She has one big brother that also likes to draw, and she thinks that his drawing is better than hers. She was aware that her social environment was surrounded by people who has an ability to draw, in which it makes her to train herself to be able to draw, and accept

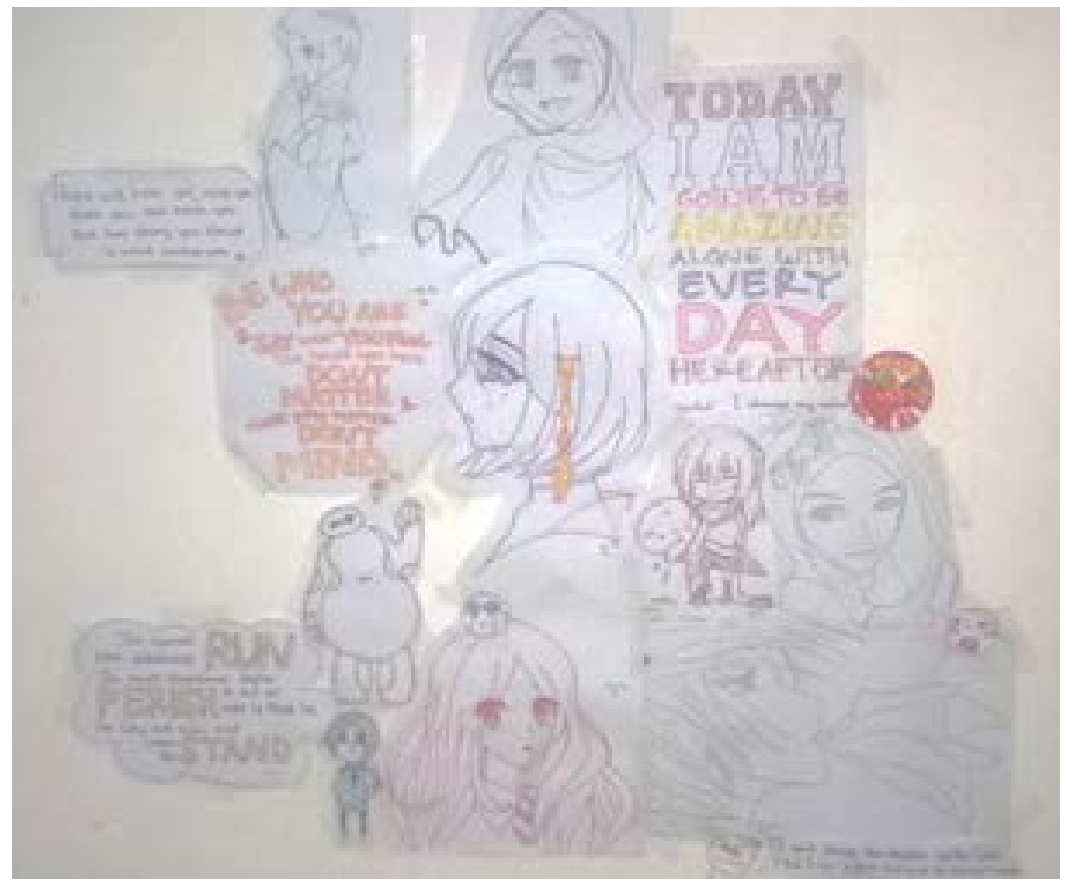

Figure 1. Rina's Sketch 
by her figured worlds (Bartlett \& Holland, 2002). She has been prohibited by her father to draw, since, in Islam, drawing a living object is not allowed because it is seen as equal divine creation. Although her literacy practices have been prohibited, she is still doing it because by drawing she could feel her real soul; she can express her feelings through drawing.

Based on the pictures, it can be seen that her drawing reflects her identity and figured worlds she participated in. Since she like anime movies art and animation movies, some of her drawing represent some of cartoon figures, such as Baymax (a robot from the Big hero 6). As I interviewed her, her figured worlds were clear that they could promote her literacy activities to present her figured worlds and identity. She said that her boarding house, where she stayed during her master study, provided her with a good internet connection. She liked to explore the anime movies produced by Japan. Her eagerness of exploring anime movies produced in Japan affects her language understanding of Japanese language, in which it makes her able to speak and understand some words in Japanese. The other interesting fact that can represent her identity is her drawing of woman wearing hijab, in which it represents her religion identity and her social interaction. She grows up in Islamic family, and she took her study in Islamic boarding school. Her eagerness of drawing is only for pleasure, and she is not thinking of creating something by her ability of drawing, when I interviewed her "why don't you make your own comic?".

The other fact that can be analyzed from her picture is her graffiti, in which it contains motivation quotes. Such

\footnotetext{
"Today I am going to be amazing along with every day here after", "Be who you are \& say what you feel 'cuz [because] those who mind don't matter \& those who matter don't mind.,
}

\begin{abstract}
"People will hate you, rate you, shake you, and break you. But how strong you stand is what makes you."
\end{abstract}

Based on the result of the interview that she did drawing is because she was lazy, and she had not any work to be done that makes her bored. The role of these two motivation quotes act as her reminder to keep the motivation up. These quotes also showed how she felt when she wrote these quotes, in which her feeling seem to be bored of her activities on that day.

Based on the analysis, it can be concluded that the role of figured worlds in somebody's identity formation affects their literacy practices. In this case Rina's identity was constructed within her figured worlds, that her family like drawing, she grows up in the Islamic family, and her social interaction promote her to shape her identity. As it is introduced by Holland (1998), figured world is a place of somebody producing identity. It is strengthened by Barton et.al. (2000) and Phal \& Rowsell (2005) that somebody's literacy practices and their literacy events actually draw their identity, in which it showed where, with whom they live, and etc. implicitly. In addition, somebody that tries to fit in some figured worlds will adopt some cultural artifacts of the figured worlds, in which it aims to develop their ability from something that they cannot do in the figured worlds. This is a kind of resistance from the negative social positioning inside the worlds (Bartlett \& Holland, 2002). It also found that literacy does not only mean the skill of reading and writing, beyond that, it also covers somebody's social practices involving written text mediated by book or even electronic devices.

\section{Conclusion}

Figure world is a place where somebody lives in and intercats with. This forms someone's identity, and therefore, can be seen from how one acts, what one reads or writes and how one's internal drives to react on something occurred 
around him or her. What one has read, written, acted or reacted determines his or her identity which reflects his surrounding, people he or she usually interact with and the way of life he or she has within the environment.

\section{References}

Bartlett, L., \& Holland, D. (2002). Theorizing the Space of Literacy Practices. Ways of Knowing Journal, 2(1), 10-22.

Barton, D., Hamilton, M., \& Ivanic, R. (2000). Situated Literacies Reading and Writing in Context. London: Routledge.

Holland, D., Jr, W. L., Skinner, D., \& Cain, C. (1998). Identity and Agency in Cultural Worlds. London: Harvard University Press.

Luttrell, W., \& Parker, C. (2001). High School Students' Literacy Practices and Identities, and the Figured World of School. Journal of Research in Reading, 24(3), 235-248.

Phal, K., \& Rowsell, J. (2005). Literacy and Education. Great Britain: Paul Chapman Publishing.

Pratiwi, R. (2014). Membangun Budaya Literasi. In Literasi Sebagai Praktik Sosial (pp. 18-34). Surabaya: Unesa University Press. 